\title{
Sumber Daya Manusia di perguruan tinggi Indonesia saat pandemi COVID-19: Bekerja dari rumah dan kebijakannya
}

\author{
Elisabeth Rukmini * 1, Maria Dwi Ardiana ${ }^{2}$ \\ ${ }^{1}$ Universitas Pembangunan Jaya \\ J1. Cendrawasih Raya Blok B7/P Bintaro Jaya, Sawah Baru, Ciputat, Tangerang Selatan 15413, Indonesia. \\ ${ }^{2}$ Universitas Universitas Katolik Indonesia Atma Jaya \\ J1. Jendral Sudirman 51, Jakarta 12930, Indonesia. \\ * Corresponding Author. Email: elisabeth.rukmini@atmajaya.ac.id
}

\section{ARTICLE INFO}

\section{Article History}

Received:

9 October 2020

Revised:

21 April 2021;

Accepted:

3 May 2021

Available online:

3 May 2021

\section{Keywords}

bekerja dari rumah; perguruan tinggi; penjaminan mutu. working from home; higher education institution; quality assurance.

\begin{abstract}
Penelitian ini bertujuan menggali penjaminan mutu dalam pengelolaan SDM sebagai hasil praktik baik selama WFH, yang diharapkan berguna bagi pengelolaan SDM di perguruan tinggi (PT). Survei daring dilakukan untuk menggali opini, perspektif, dan praktik dari stakeholder. Hasil menunjukkan 90\% responden berasal dari PTS dan $73 \%$ berlokasi di Jakarta $(\mathrm{N}=198)$. Responden $(85 \%)$ setuju PT telah mempersiapkan WFH, penetapan kebijakan, virtual workspace, SDM, mekanisme monitoring dan evaluasi. Responden $(80 \%)$ mengapresiasi persiapan dan pengambilan keputusan WFH. Responden (50\%) memenuhi 51-75\% tuntutan pekerjaan selama WFH. Responden $(52 \%)$ menyatakan unitnya mencapai $51-75 \%$ target kerja. Responden (87\%) mengapresiasi mekanisme monitoring. Apresiasi responden $(82 \%)$ diberikan pada efektivitas WFH. Responden ( $88 \%)$ setuju WFH sebagai opsi cara kerja mendatang. Responden setuju (38\%) 3+2 hari (WFH+WFO) per minggu. Responden setuju (35\%) menukar $15-30 \%$ biaya transpor dengan WFH. Pertanyaan terbuka menunjukkan agar WFH didukung akses internet dan virtual workspace yang memadai. Penelitian ini menunjukkan praktik teladan sepanjang WFH yang dapat distandarkan menjadi penjaminan mutu pengelolaan SDM, di antaranya standar pengambilan keputusan, mekanisme monev, dan fasilitas daring.
\end{abstract}

This research aimed to explore the quality assurance in human resources management as best practices of WFH, that would be beneficial for HR management in higher education institutions (HEI). An online survey was done to seek opinions, perspectives, and meaningful practices among HEI stakeholders. Results show 90\% of respondents are from private universities, and $73 \%$ are located in Jakarta ( $N$ total 198). Respondents (85\%) agree there is preparation toward WFH, the policy, virtual workspace, HR, monitoring and evaluation mechanism. Respondents (80\%) appreciate the WFH preparation and decision. Respondents (50\%) complete 51-75\% of the work during WFH. Respondents (52\%) state their unit achieved $51-75 \%$ of the target during WFH. Respondents (87\%) appreciate the monitoring mechanism. Their appreciation (82\%) is given to the effectiveness of WFH. Respondents agree (88\%) of WFH as an option for the future of working. Respondents agree (38\%) of $3+2$ days (WFH+WFO) per week. Respondents agree (35\%) to exchange their 15-30\% of transport fees to WFH. The open-ended questions show WFH should be supported by adequate access to the internet and virtual workspace. This research shows best practices of WFH, which could be standardized as QA toward HR system, including the standards of decision making, monitoring and evaluation, and online facilities.

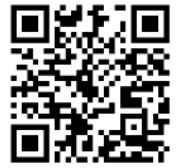

This is an open access article under the $\underline{\text { CC-BY-SA }}$ license.

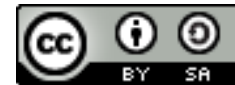

How to cite:

Rukmini, E., \& Ardiana, M. (2021). Sumber Daya Manusia di perguruan tinggi Indonesia saat pandemi COVID-19: Bekerja dari rumah dan kebijakannya. Jurnal Akuntabilitas Manajemen Pendidikan, 9(1), 20-33.

doi:https://doi.org/10.21831/jamp.v9i1.34997 


\section{PENDAHULUAN}

Pandemi Corona Virus Disease (COVID)-19 dan Pembatasan Sosial Berskala Besar (PSBB) sudah mempengaruhi manajemen pendidikan tinggi di Indonesia. Kementerian Pendidikan dan Kebudayaan (Kemdikbud) Republik Indonesia menetapkan kebijakan belajar di rumah dan bekerja di rumah (working from home atau WFH) sejak minggu ketiga bulan Maret 2020 (Nizam, 2020). Divisi Sumber Daya Manusia (SDM) dan pimpinan perguruan tinggi (PT) harus mengelola kebiasaan baru WFH dan memelihara efektivitas WFH di antara SDM PT. Perubahan yang amat mendadak ini menciptakan praktik-praktik dan standar WFH selama masa pandemi dan kenormalan baru. Meskipun di awal penentuan WFH belum terdapat persiapan yang matang, PT di Indonesia melalui Divisi SDM harus menemukan terobosan bermakna untuk melakukan standarisasi praktik kerja SDM-nya. Standar tersebut dapat menjadi praktik baik bahkan best practices sehingga berguna tidak saja pada masa pandemi dan kenormalan baru, tetapi juga dalam penjaminan mutu standar kerja WFH di masa mendatang.

Istilah bekerja di luar kantor sangat beragam, misalnya telework, e-work, remote work, flexy working hours, ataupun working from home. Berdasarkan definisi, WFH yang kita alami dalam masa pandemi COVID-19 ini sangat dekat dengan definisi telework dan $e$-work. Telework dapat diartikan sebagai segala tipe pekerjaan yang dapat dikerjakan di luar kantor utama dengan tetap berhubungan melalui telekomunikasi dengan kantor utama (Charalampous et al., 2019). Sementara itu, dengan perkembangan teknologi digital, maka istilah $e$-work tampaknya lebih tepat menggambarkan WFH masa kini; e-work adalah perkejaan yang dapat diselesaikan secara virtual. Pekerja dengan tipe $e$-work adalah pekerja yang bekerja dengan secara penuh waktu di rumah dengan berkomunikasi melalui media elektronik seperti surel perusahaan, intranet, internet, melakukan pertemuan virtual terbatas dengan atasan dan kelompok kerjanya. Dengan kerangka inilah kita mendefinisikan WFH perguruan tinggi kita di masa pandemi ini.

Kerangka WFH pada saat pandemi dianggap berbeda oleh para praktisi dan peneliti manajemen organisasi. Bila pada masa normal tanpa pandemi, WFH dilakukan sebagai pilihan, maka pada masa pandemic, WFH bukanlah pilihan lagi. Hal ini dilakukan dalam kondisi terpaksa oleh keadaan dan dipaksa oleh aturan kesehatan dalam kedaruratan. Fakta tersebut tak terbantahkan akan memengaruhi cara kerja SDM PT. Kondisi darurat dan tidak terlatih menjadi faktor penghambat WFH (Waizenegger et al., 2020). Dalam konteks PT di Indonesia yang mayoritas mengadakan pembelajaran dan menjalani proses bisnisnya dengan tatap muka, maka kendala darurat pandemi dan WFH pasti melingkupi SDM PT. Kerangka WFH dalam kondisi ini dengan demikian belum mencatatkan standar kerja yang disepakati bersama.

Para peneliti sebelumnya telah membahas standar WFH dalam artian well-being (meliputi kesejahteraan, kesehatan mental, kenyamanan, serta kebahagiaan). Sebagai sebuah contoh, peneliti di Australia membahas kesehatan mental para ayah dan ibu yang bekerja dari rumah (Hokke et al., 2020). Hokke et al. (2020) menggambarkan pengaturan kerja yang fleksibel memberikan dampak positif pada kesehatan keluarga; meskipun demikian, pengaturan itu saja tanpa didampingi dengan dukungan problem solving bagi keluarga tidak memadai bagi tingkat kesejahteraan para ayah dan ibu yang bekerja dari rumah. Studi serupa pada pekerja kerah putih (white collar salary-paid employees) menunjukkan perbedaan WFH berdasarkan sukarela versus keharusan (voluntary vs involuntary); dari studi ini juga ditinjau bahwa kesehatan mental para pekerja dengan temuan voluntary WFH lebih menjanjikan kesehatan (Kaduk et al., 2019). Pengamatan mengenai alokasi waktu kerja, lokasi kerja, kesehatan, dan luaran kerja telah dilakukan dengan membandingkan kelompok kontrol yang bekerja di kantor dengan kelompok intervensi; hasil penelitian ini tidak memberikan perbedaan (Nijp et al., 2016).

Studi tentang standar WFH masih menjadi agenda yang diusulkan oleh penelitian terdahulu (Croucher \& Rizov, 2015; Kotey \& Sharma, 2016). Kontrol terhadap kualitas WFH dari sisi perencanaan, implementasi, monitoring, dan evaluasi secara khusus di perguruan tinggi belum dilakukan dengan terstandar. Sementara itu, para peneliti mengakui WFH di berbagai sektor tentu memiliki standar tersendiri (Kröll et al., 2018; Pitt-Catsouphes et al., 2015; Williams et al., 2018). Dalam kerangka perguruan tinggi di Indonesia, WFH adalah bentuk kerja baru yang dipraktikkan dalam keadaan darurat sehingga tak ada pengalaman perencanaan pengelolaan SDM, pemantauan, dan eva- 
luasi yang telah terstandar. Standar sangat mungkin ditumbuhkan dari pengalaman baik (best practices) selama penerapan WFH pada masa pandemi COVID-19 ini. Melalui pengalaman yang direkam dengan baik, standar dapat menjadi sistem penjaminan mutu untuk WFH di masa mendatang setelah pandemi berakhir. Oleh karena itu, studi terhadap pengalaman saat ini akan bermakna bagi perkembangan pengelolaan SDM PT di Indonesia.

Penelitian ini bertujuan untuk mengetahui aspek-aspek penjaminan mutu terhadap manajemen SDM perguruan tinggi, pada masa pandemi dan kenormalan baru melalui praktik atau pengalaman nyata para pelakunya, dengan harapan hal ini akan berguna bagi standar manajemen SDM PT di masa mendatang. Untuk mencapai tujuan penelitian tersebut, kami melakukan survei daring dengan menggali opini, perspektif, dan praktik-praktik bermakna di antara para pelaku (stakeholders) perguruan tinggi selama WFH. Survei menargetkan stakeholders PT di Indonesia terutama yang berasal dari kelompok: (1) top managerial PT, (2) kepala unit pendukung, (3) dosen, and (4) staf unit pendukung.

\section{METODE}

Penelitian ini merupakan studi deskriptif dan eksploratif, dengan pendekatan survei terhadap berbagai level pelaku WFH di perguruan tinggi di Indonesia. Survei dilakukan melalui daring dengan online form untuk menggali aspek-aspek WFH dan kaitannya dengan penjaminan mutu SDM di perguruan tinggi. Survei ditujukan bagi: (1) para pemangku jabatan penentu kebijakan internal PT di level universitas (top managerial level) yang membuat kebijakan utama untuk WFH, (2) para kepala unit pendukung, (3) para pelaku WFH sebagai dosen, dan (4) para pelaku WFH sebagai tenaga kependidikan.

Survei yang dilakukan berisi pertanyaan dan pernyataan mengenai aspek-aspek yang berkaitan dengan kebijakan, praktik, dan evaluasi terhadap WFH di masa pandemi COVID-19 dan masa kenormalan baru di perguruan tinggi. Pernyataan dan pertanyaan dalam survei terbagi menjadi tiga bagian besar, yaitu: pertanyaan demografik, pernyataan tertutup dan pertanyaan terbuka. Terdapat empat pernyataan demografik yang menanyakan kategori responden, bekerja di PT negeri atau swasta, tempat kampus PT berada, dan latar belakang keilmuan responden. Seluruh pernyataan demografik dapat dijawab dengan memilih pilihan yang ada. Pernyataan tertutup terdiri dari 26 pernyataan. Sebanyak sepuluh butir dari pernyataan tertutup merupakan survei dengan skala Likert tingkat kesetujuan 1 hingga 4 (1: sangat tidak setuju hingga 4: sangat setuju) terhadap pernyataan terkait. Sebanyak 16 butir dari pernyataan tertutup menyediakan pilihan jawaban dengan permintaan satu jawaban terpilih di setiap pernyataan. Survei juga memiliki empat pertanyaan terbuka untuk meminta pendapat utama responden dan tiga pernyataan yang meminta responden menentukan skor terhadap pernyataan.

Target sasaran survei daring ini minimal lima perguruan tinggi di Indonesia. Cara pengambilan sampel dilakukan dengan teknik purposive sampling, dengan pembagian tiap kelompok sebagai berikut: (1) Kelompok 1: tiga responden, top level manager, rektorat, presidential office, (2) Kelompok 2: 25 responden, kepala biro unit pendukung, (3) Kelompok 3: 75 responden, dosen, dan (4) Kelompok 4: 40 responden, tenaga kependidikan. Analisis data dilakukan dengan cara deskriptif. Untuk hasil pertanyaan terbuka dilakukan dengan analisis tema utama (content analysis).

\section{HASIL DAN PEMBAHASAN}

\section{Hasil}

\section{Demografi Responden}

Hasil demografi responden menunjukkan total responden 198 orang dengan persentase terbanyak responden berasal dari perguruan tinggi swasta (PTS) (90\%) yang berlokasi di Jakarta, Bogor, Tangerang, Bekasi (Jabodetabek) (73\%). Gambar 1 menunjukkan asal PT. Dilihat dari kelompok responden, sudah sesuai dengan besaran yang ingin dicapai dengan mayoritas (43\%) ada- 
lah tenaga kependidikan. Jumlah kelompok kedua sedikit lebih kecil dibandingkan jumlah yang direncanakan, sebagaimana disajikan dalam Tabel 1. Kelompok dua adalah kelompok kepala biro unit pendukung. Dipandang dari bidang ilmu, responden terbanyak berlatar belakang ilmu sosial dan humaniora, sebagaimana ditampilkan pada Gambar 2.

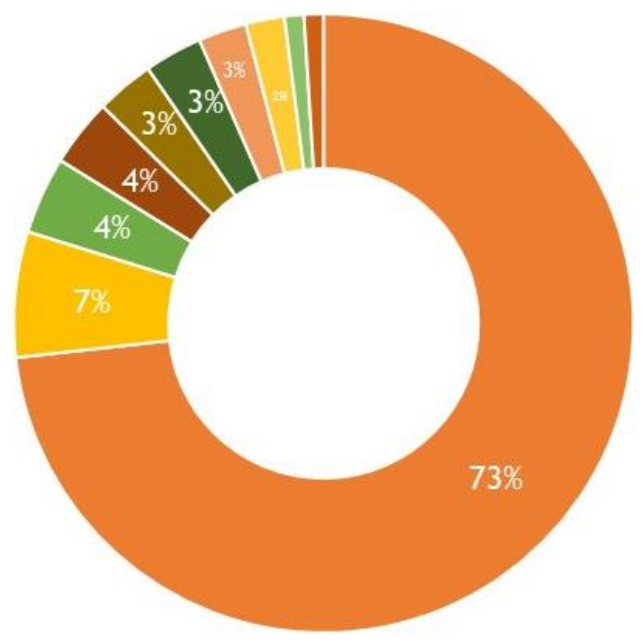

\section{- Jabodetabek \\ - Sumatra \\ - Jawa Barat}

\author{
Kalimantan \\ - Jawa Timur \\ - Bali dan Nusa Tenggara
}

- DIY

- Sulawesi

- Maluku

Gambar 1. Asal Perguruan Tinggi Responden

Tabel 1. Demografi Responden

\begin{tabular}{|c|c|}
\hline Kelompok & $\mathbf{N}$ (orang) \\
\hline 1: top level manager, rektorat, presidential office & 8 \\
\hline 2: kepala biro unit pendukung & 26 \\
\hline 3: dosen & 78 \\
\hline 4: tenaga kependidikan & 86 \\
\hline Total & 198 \\
\hline
\end{tabular}

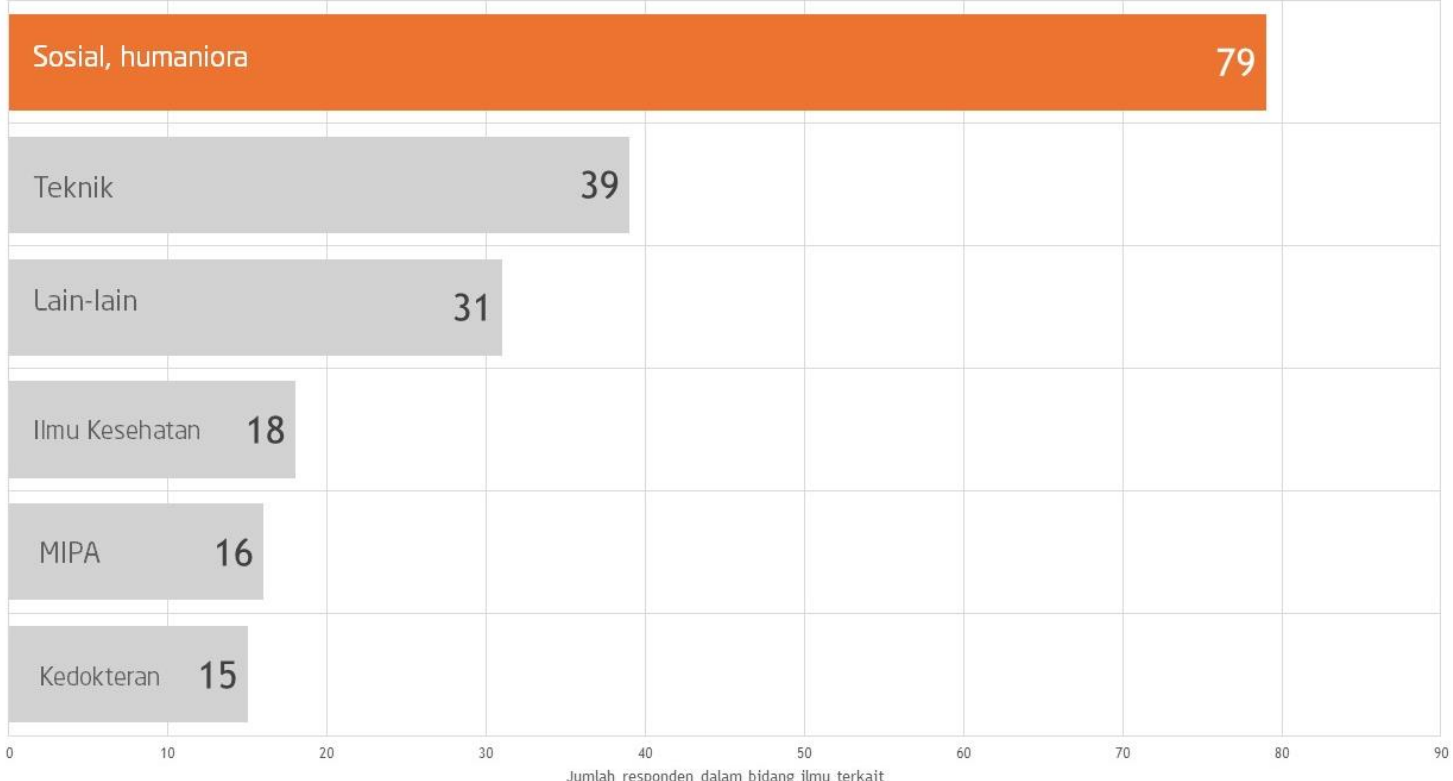

Gambar 2. Latar Belakang Bidang Ilmu Responden 


\section{Persiapan WFH}

Penilaian responden terhadap persiapan WFH di PT dianggap sudah baik. Sebanyak $85 \%$ responden setuju bahwa PT sudah melakukan persiapan sebelum WFH, sebagaimana disajikan dalam Gambar 3. Sementara itu bila ditinjau dari persiapan yang sudah dilakukan, pendapat responden bervariasi (Gambar 4). Persiapan mengenai fasilitas untuk kerja daring dengan paket pulsa data dan pemantauan serta mekanisme pemantauan belum dipersiapkan dengan cukup matang.

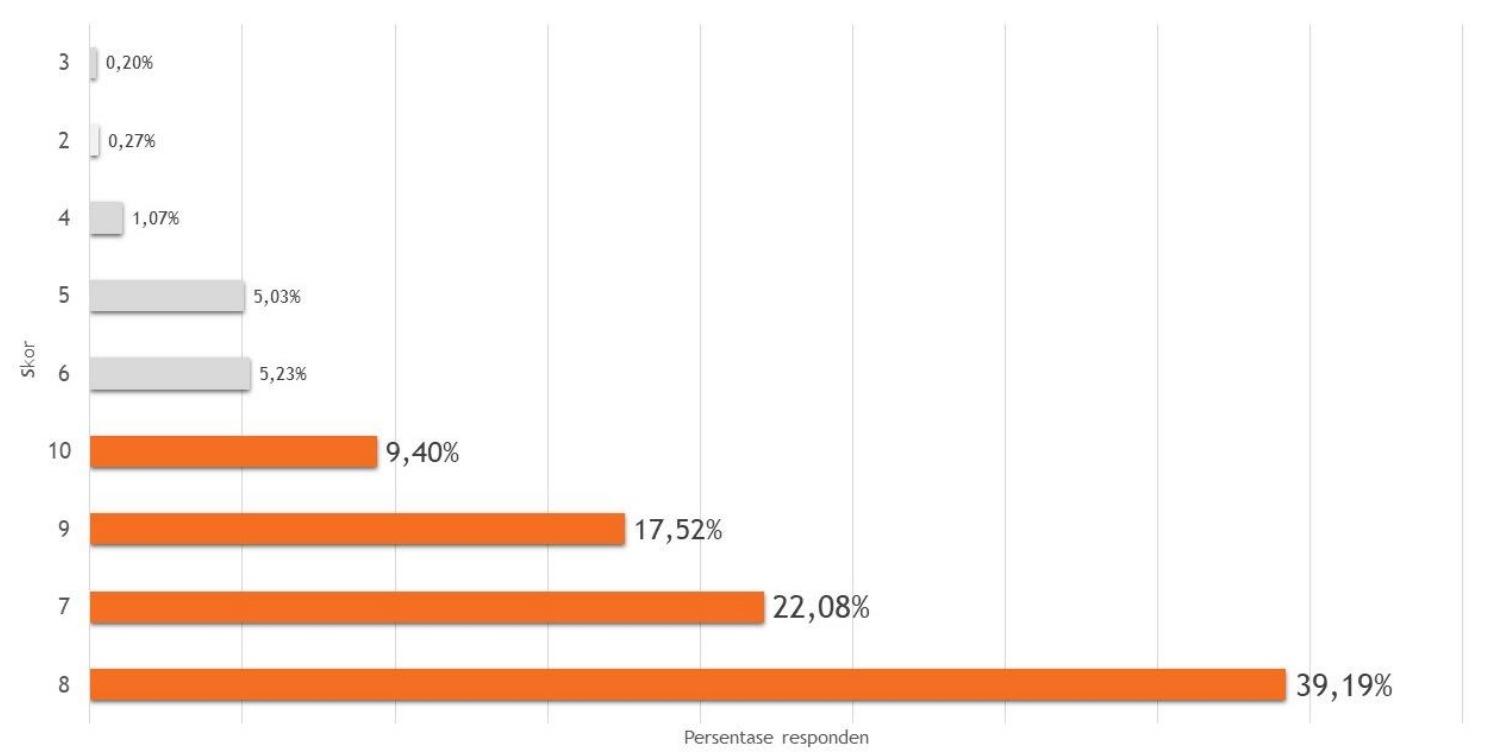

Gambar 3. Penilaian Responden tentang Persiapan WFH Secara Keseluruhan

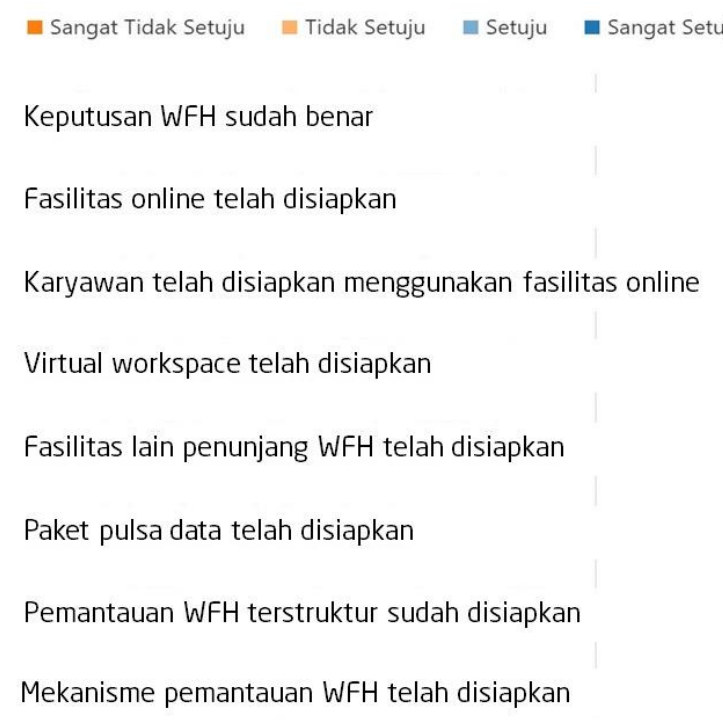

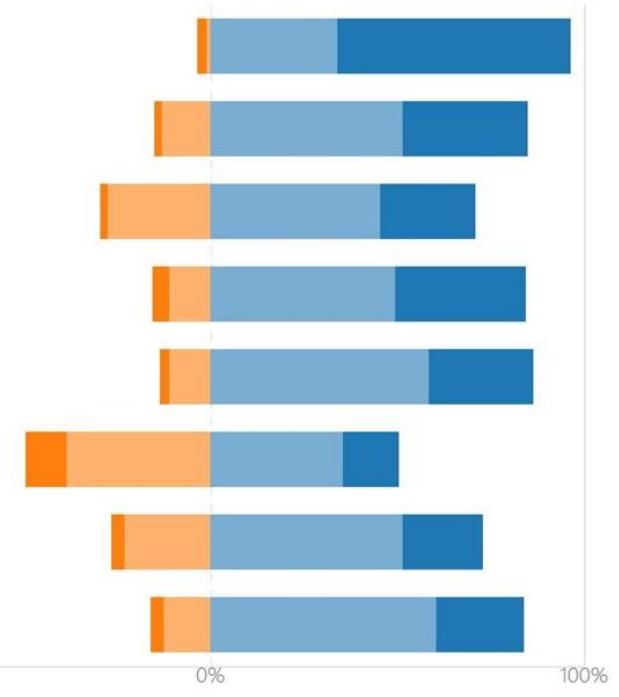

Gambar 4. Pendapat Responden Mengenai Persiapan WFH

\section{Implementasi WFH}

Sepanjang implementasi WFH, 38\% responden menyatakan dapat menyelesaikan sekitar 75$100 \%$ target pekerjaan dan 50\% responden menyatakan dapat menyelesaikan sekitar $51-75 \%$ pekerjaan mereka (Gambar 5). Sejalan dengan pendapat ini, 52\% responden menyatakan bahwa unit kerja tempat mereka tergabung dapat mencapai 51-75\% dari target unit selama WFH (Gambar 6). Terlihat adanya konsistensi antara pendapat terhadap personal dan unit kerjanya. Patut dicatat pula bahwa sekitar 19\% responden menyatakan capaian kinerja unitnya kurang dari 50\% target kerja. 


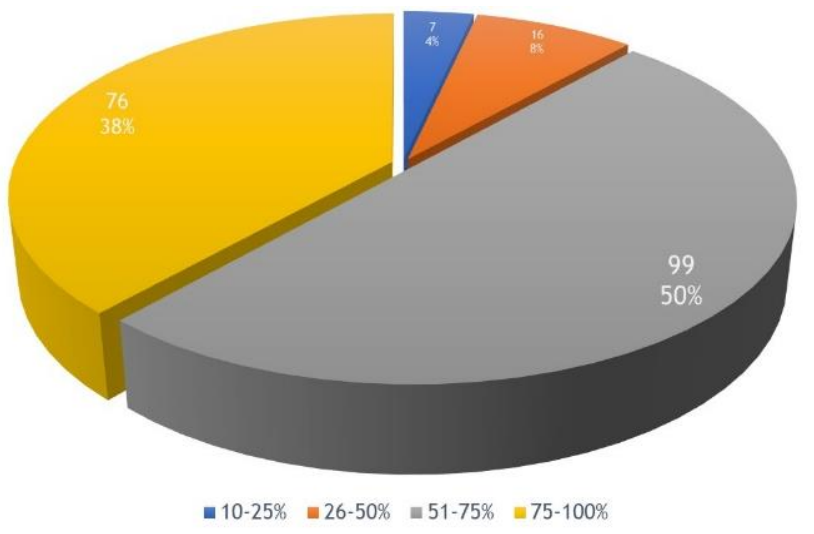

Gambar 5. Pendapat Responden Mengenai Persentase Pekerjaan yang Diselesaikan Selama WFH

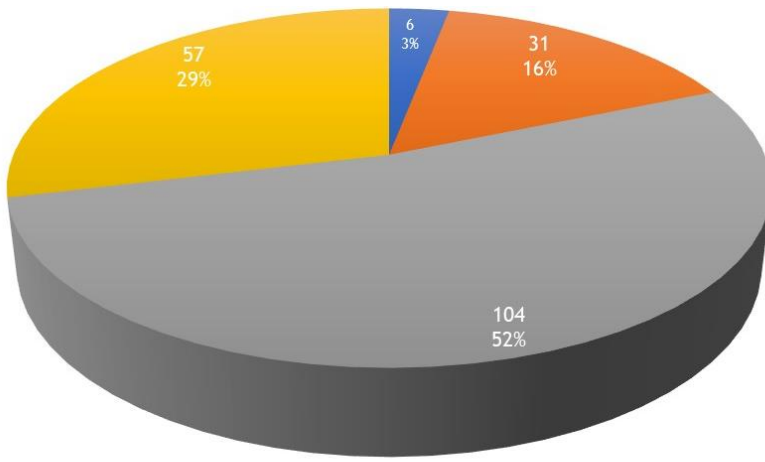

$\square 10-25 \% \quad-26-50 \% \quad \square 51-75 \% \quad \square 75-100 \%$

Gambar 6. Capaian Kinerja Unit Selama WFH

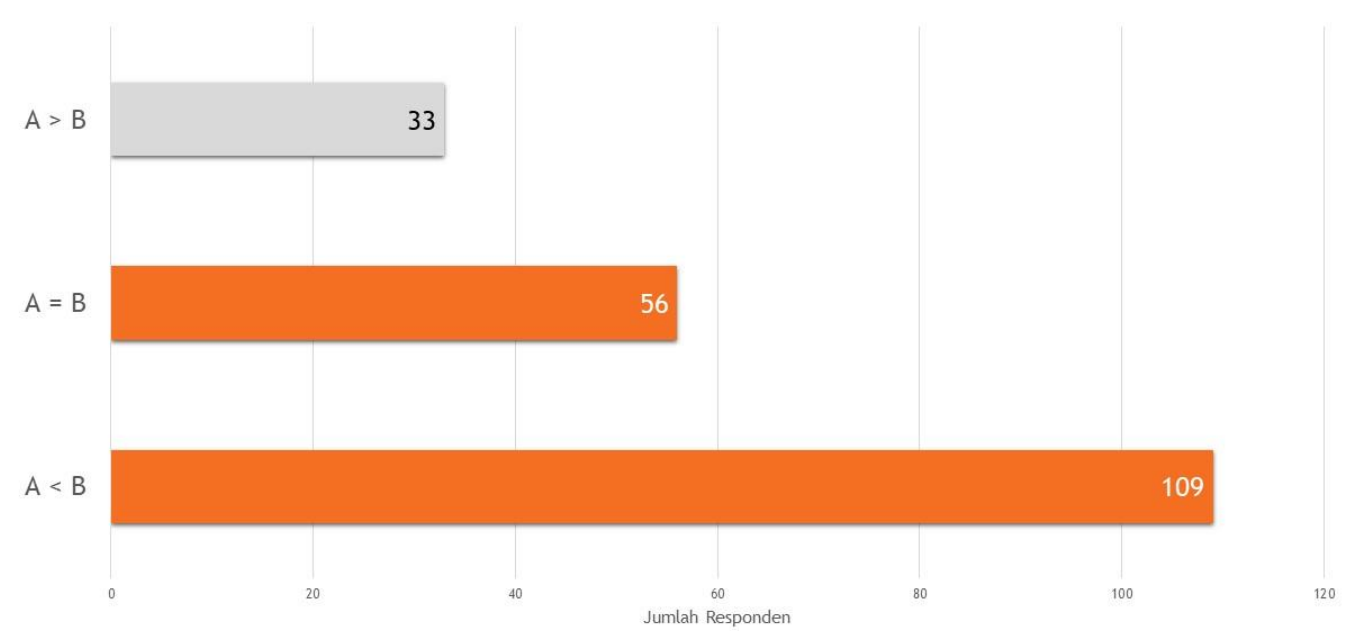

Gambar 7. Penilaian Responden Terhadap Capaian Kinerja Antara WFO dengan WFH (A: Capaian Kinerja Saat WFH, B: Capaian Kinerja Saat WFO)

Konsistensi pendapat tentang kinerja selama WFH terlihat pada Gambar 7. Kepada responden ditanyakan, bila diminta membandingkan antara working from office (WFO) dengan WFH, seperti apakah capaian kinerjanya. Sebanyak 55\% (N=109) menunjukkan hasil WFO lebih besar daripada WFH. Sekitar 28\% (N=56) menunjukkan capaian yang sama. Pertanyaan selanjutnya, bila kinerja ini dipandang dari sudut dosen dan tendik, pada Gambar 8 tampak hasil pendapat responden terhadap kinerja harian dosen dan tendik. Menurut $31 \%$ responden, dosen dapat menyelesaikan $75-$ $100 \%$ target kerja selama WFH, hal ini lebih besar dari $27 \%$ responden yang berpendapat tendik dapat menyelesaikan targetnya antara $75-100 \%$ target kerja. 

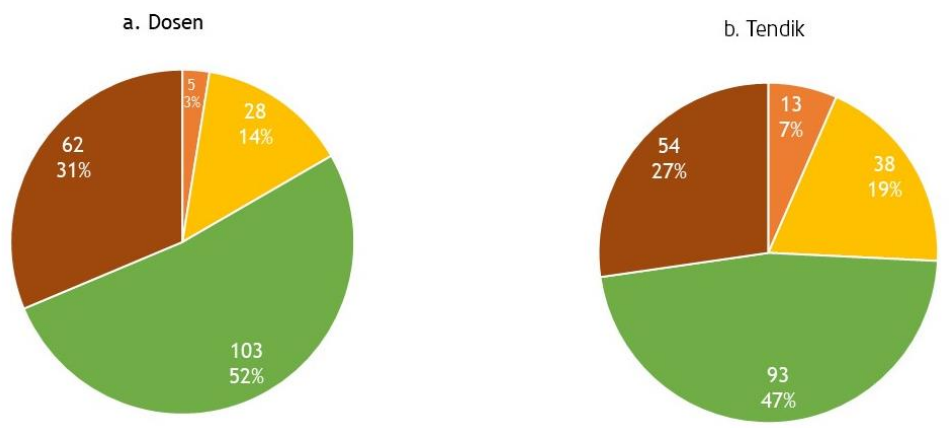

$=10-25 \%=26-50 \%=51-75 \% \quad-75-100 \%$

Gambar 8. Perbandingan Dosen (A) Vs Tendik (B) dalam Mencapai Kinerja Harian Saat WFH

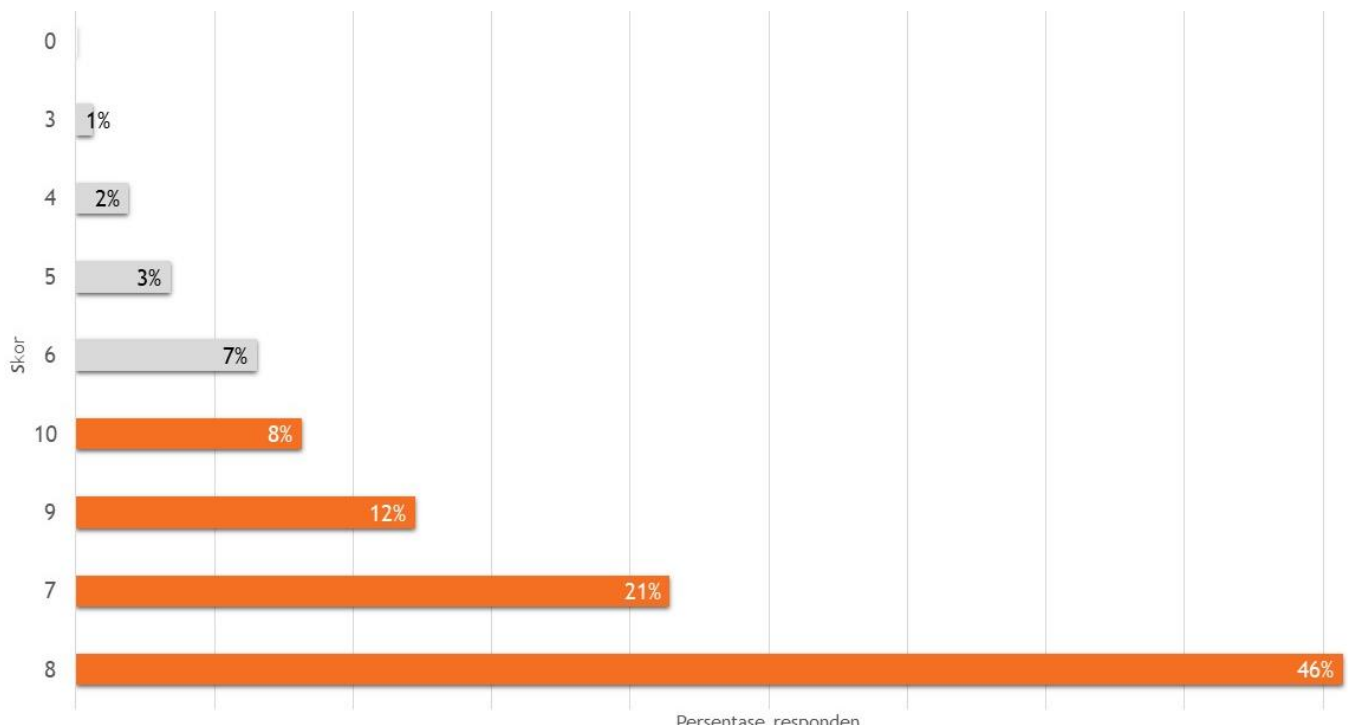

Gambar 9. Penilaian Responden Terhadap Pemantauan Kerja Saat WFH

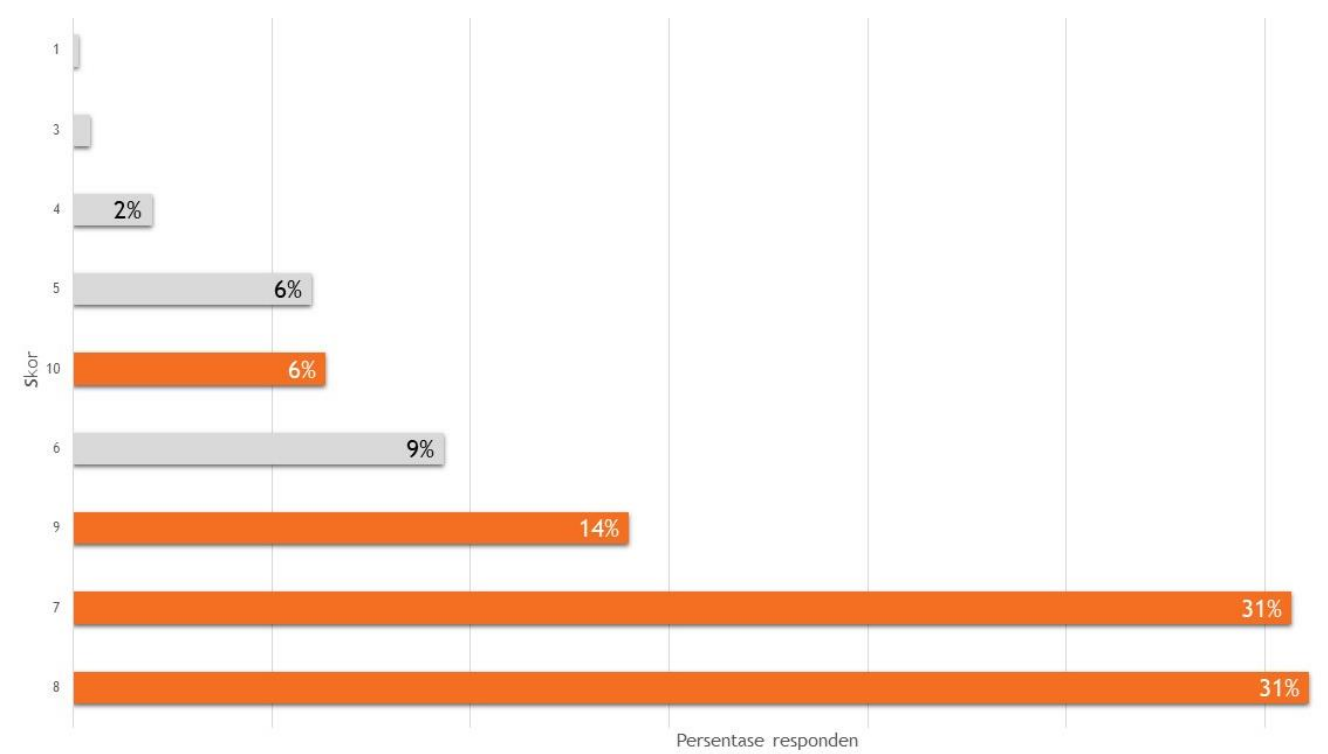

Gambar 10. Penilaian Responden Terhadap Efektivitas WFH

Ketika pertanyaan digali lebih dalam tentang karya tri darma dosen, 57\% responden berpendapat dosen dapat menyelesaikan separuh pekerjaan penelitian selama WFH. Sementara untuk karya pengabdian kepada masyarakat, $11 \%$ responden berpendapat dosen dapat menyelesaikan minimal 75\% target kerja abdimas. Dari segi mutu pekerjaan, $11 \%$ responden menilai tendik dapat me- 
ngerjakan tugasnya dengan mutu kerja yang sama antara WFH dan WFO. Hal yang sama juga terdapat pada mutu pekerjaan yang dihasilkan oleh dosen. Ketika ditanyakan kepada responden tentang penilaian mereka terhadap pemantauan kerja selama WFH, 87\% responden memberi apresiasi (Gambar 9), sejalan dengan apresiasi responden (82\%) terhadap efektivitas WFH (Gambar 10).

\section{Evaluasi WFH}

Dalam keadaan normal baru, responden setuju (88\%) WFH dimasukkan sebagai pilihan cara bekerja di luar bekerja di kantor (WFO). Responden setuju (38\%) bahwa pilihan $3+2$ hari kerja (WFH+WFO) dalam satu minggu merupakan pilihan yang paling sesuai dengan SDM di PT Indonesia (Gambar 11). Pilihan terbesar kedua (29\% responden) pada satu hari kerja WFH dan empat hari kerja WFO. Hal ini tentu dapat memberikan gambaran bagi manajemen SDM di PT. Sementara itu, ketika digali dengan pertanyaan tentang persentase uang transpor yang bersedia ditukar dengan WFH, 35\% responden setuju untuk menukarkan 15-50\% uang transpor mereka dengan WFH (Gambar 12). Dengan demikian, manajemen PT dapat melakukan kalkulasi secara transparan dan pekerjaan dapat dinilai dari pilihan-pilihan yang telah difasilitasi oleh manajemen SDM PT.

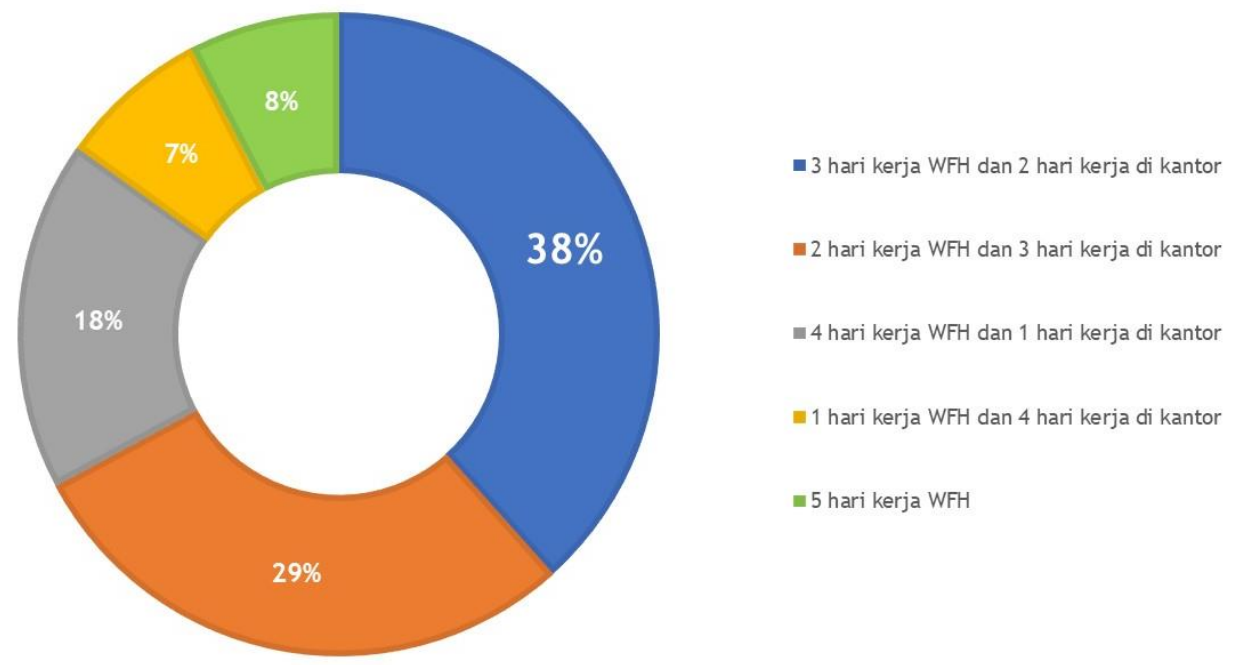

Gambar 11. Pilihan Responden Mengenai Komposisi WFH+WFO dalam Satu Minggu Hari Kerja

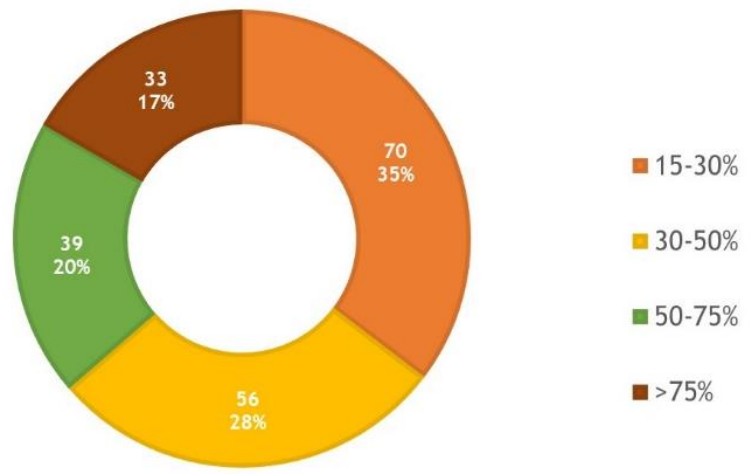

Gambar 12. Pendapat Responden atas Pernyataan: "Persentase Uang Transpor dalam Satu Minggu, Yang Bersedia Saya Tukar dengan WFH Adalah:"

Pertanyaan terbuka meliputi empat hal utama: (1) hal positif, (2) hal yang perlu diperhatikan, (3) keberlanjutan WFH, (4) hal yang paling penting disediakan PT. Rangkuman analisis konten respon terhadap pertanyaan terbuka terdapat pada Tabel 2. Tiga kategori bertanda bintang dalam tabel merupakan pendapat paling sering ditemui dalam tiap kelompok. Efisiensi waktu, adanya komunikasi intensif melalui daring, dan kebersamaan dalam keluarga menjadi hal-hal positif yang paling sering ditemui. Dalam kategori ini terdapat pula efektivitas kerja yang dirasakan oleh responden. 
Tabel 2. Kategori Respon Pernyataan Terbuka

\begin{tabular}{|c|c|c|}
\hline Pernyataan & Kategori Respon & Definisi Kategori \\
\hline \multirow[t]{9}{*}{ Hal Positif } & Efisien* & Adanya efisiensi waktu karena WFH. \\
\hline & Daring* & $\begin{array}{l}\text { Lebih banyak komunikasi, koordinasi secara daring, pertemuan } \\
\text { daring, mengajar daring, lebih sering berkomunikasi. }\end{array}$ \\
\hline & Keluarga bermutu* & $\begin{array}{l}\text { Adanya kesempatan untuk semakin dekat dengan keluarga karena } \\
\text { WFH. }\end{array}$ \\
\hline & Efektif & $\begin{array}{l}\text { Bekerja dengan efektif karena lebih fokus, mudah konsentrasi, } \\
\text { tidak terganggu dering telpon atau distraksi lainnya. }\end{array}$ \\
\hline & Pengembangan diri & $\begin{array}{l}\text { Adanya kesempatan mengembangkan diri, belajar hal baru, } \\
\text { terdapat perubahan ke arah positif. }\end{array}$ \\
\hline & $\begin{array}{l}\text { Tanggung jawab } \\
\text { mandiri }\end{array}$ & $\begin{array}{l}\text { Merasakan perkembangan diri dalam hal tanggung jawab } \\
\text { personal untuk tetap berkarya meski tidak ke kantor, self- } \\
\text { monitoring, lebih mandiri. }\end{array}$ \\
\hline & Sehat & $\begin{array}{l}\text { Kesempatan berolahraga teratur dan menjaga kesehatan karena } \\
\text { WFH. }\end{array}$ \\
\hline & Transpor & $\begin{array}{l}\text { Adanya penghematan biaya, energi, waktu untuk tidak perlunya } \\
\text { melakukan transportasi ke kantor. }\end{array}$ \\
\hline & $\begin{array}{l}\text { Menekan } \\
\text { persebaran COVID }\end{array}$ & $\begin{array}{l}\text { Turut berperan aktif menekan persebaran COVID-19 dengan } \\
\text { tetap bekerja di rumah. }\end{array}$ \\
\hline \multirow[t]{7}{*}{$\begin{array}{l}\text { Hal yang perlu } \\
\text { diperhatikan }\end{array}$} & Fasilitas* & $\begin{array}{l}\text { Fasilitas berupa akses internet, pulsa data, akses terhadap } \\
\text { hardware, akses data manajemen. }\end{array}$ \\
\hline & Pemantauan kerja* & Perlunya pemantauan kerja dari atasan tiap unit terhadap anggota. \\
\hline & Direksi* & Perlunya arahan dari atasan dengan jelas dan tertulis. \\
\hline & $\begin{array}{l}\text { Kesehatan fisik dan } \\
\text { mental }\end{array}$ & $\begin{array}{l}\text { Perlunya perhatian terhadap kondisi kesehatan fisik dan mental } \\
\text { karyawan, perlu adanya konseling, kontrol terhadap kesehatan. }\end{array}$ \\
\hline & Kapabilitas & $\begin{array}{l}\text { Perlunya perhatian terhadap karyawan yang belum terampil } \\
\text { dengan penggunaan virtual working space. }\end{array}$ \\
\hline & Aktivitas di kantor & $\begin{array}{l}\text { Ada beberapa aktivitas yang tetap harus dilakukan di kantor, } \\
\text { perlunya manajemen untuk hal ini. }\end{array}$ \\
\hline & Alokasi waktu kerja & $\begin{array}{l}\text { Waktu atau jam kerja WFH perlu ditentukan sehingga tidak } \\
\text { menjadi potensi masalah pribadi dan keluarga. }\end{array}$ \\
\hline \multirow{5}{*}{$\begin{array}{l}\text { Keberlanjutan } \\
\text { WFH }\end{array}$} & WFH dilanjutkan* & Opsi WFH tetap dilanjutkan meskipun tidak lagi pandemi. \\
\hline & $\begin{array}{l}\text { Kombinasi } \\
\text { WFH+WFQ* }\end{array}$ & Adanya pilihan kombinasi antara WFH+WFO di masa \\
\hline & Mekanisme* & $\begin{array}{l}\text { Adanya mekanisme yang mengatur sistem WFH, WFO, SOP, job } \\
\text { desk, dan monitoring. }\end{array}$ \\
\hline & Prosedur kesehatan & Adanya prosedur kesehatan saat kenormalan baru. \\
\hline & Online learning & Online learning tetap perlu dilanjutkan meskipun tidak pandemi. \\
\hline \multirow[t]{8}{*}{$\begin{array}{l}\text { Hal yang perlu } \\
\text { disediakan PT }\end{array}$} & Fasilitas* & $\begin{array}{l}\text { Fasilitas berupa akses internet, pulsa data, akses terhadap } \\
\text { hardware, akses data manajemen. }\end{array}$ \\
\hline & Mekanisme* & $\begin{array}{l}\text { Adanya mekanisme yang mengatur sistem WFH, WFO, SOP, job } \\
\text { desk, dan monitoring. }\end{array}$ \\
\hline & Kebijakan/direksi* & Perlunya kebijakan dan arahan dari atasan yang jelas dan tertulis. \\
\hline & Informasi & $\begin{array}{l}\text { Kabar/berita penting yang disosialisasikan kepada seluruh } \\
\text { karyawan. }\end{array}$ \\
\hline & Perangkat & Adanya balkesmas dan alat kesehatan dasar yang terjangkau \\
\hline & kesehatan & karyawan bila ada WFH ataupun kombinasi WFH+WFO \\
\hline & Pelatihan & Adanya dukungan pelatihan bagi peningkatan kapabilitas \\
\hline & & karyawan untuk menggunakan virtual working space. \\
\hline
\end{tabular}

*respon paling banyak disebut dalam tiap kategori

Apabila dikaitkan dengan hasil survei pernyataan tertutup sebagaimana disajikan dalam Gambar 5, Gambar 6, Gambar 7, dan Gambar 8, memang efektivitas kerja tidak muncul sebagai yang utama. Responden lebih mengedepankan efisiensi dalam hal waktu dan meningkatnya mutu hubungan dengan keluarga. Pemantauan kerja, mekanisme kerja, serta kebijakan atau direksi atasan termasuk kategori yang muncul di tiga respon utama dalam pernyataan terbuka responden. Hal ini 
berkaitan juga dengan hasil survei pertanyaan tertutup sebagaimana disajikan pada Gambar 9 dan Gambar 10. Keberlanjutan WFH menurut responden tetap perlu dilanjutkan termasuk dengan kombinasi WFH+WFO.

\section{Pembahasan}

Aspek-aspek penjaminan mutu meliputi: perencanaan, implementasi, monitoring, evaluasi. Dalam tiap aspek tersebut terdapat standar mutu minimal. Penentuan standar-standar ini dapat dilakukan secara top down policy, misalnya berbasiskan pada aturan yang lebih tinggi seperti peraturan dan petunjuk teknis pemerintah atau asosiasi profesi. Standar juga dapat berasal dari buttom up solution, yang tercipta melalui praktik baik atau solusi riil yang dilakukan komunitas pendidikan (Kholili \& Fajaruddin, 2020; Kusumah \& Yusuf, 2020) termasuk di dalamnya berdasarkan praktik baik manajemen SDM dalam PT. Praktik baik ini dapat diimplementasikan sebagai bagian dari penjaminan mutu SDM di PT (Sulaiman \& Wibowo, 2016).

Hasil penelitian ini menunjukkan apresiasi pada segi perencanaan pengambilan keputusan WFH. Dalam perencanaan terdapat: standar pengambilan keputusan, standar persiapan kerja atau mekanisme kerja WFH dalam masa pandemi COVID-19. Meskipun penetapan WFH sudah dipandang baik, dalam pernyataan monitoring dan evaluasi serta pernyataan terbuka, jelaslah mekanisme WFH perlu ditetapkan. Hal ini dapat menjadi standar baru WFH dari pengambilan kebijakan, standar kerja, standar penilaian kinerja, standar monitoring dan evaluasi.

Dalam bagian implementasi WFH, penilaian responden mengenai pekerjaan yang diselesaikan sepanjang WFH dan bagaimana unit mencapai kinerjanya masih belum maksimal. Mayoritas responden menyelesaikan 50\% dari target kerja. Hal ini berarti efektivitas kerja belum terjadi. Ini sesuai dengan temuan pada pertanyaan terbuka. Oleh karena itu, mekanisme kerja WFH perlu didefinisikan, sehingga mekanisme task-based oriented menjadi sangat perlu. Dalam mekanisme taskbased, luaran menjadi standar penilaian kinerja seseorang ataupun unit atau tim. Dengan demikian, standar luaran merupakan bagian dari standar sistem kerja WFH yang dapat dituliskan oleh pimpinan PT. Direksi dalam bentuk kebijakan dan turunannya menjadi penting dalam memantau kinerja dan luaran karyawan serta unit. Keterbatasan survei ini adalah karena sifatnya yang self-assessment, maka pertanyaan tentang efektivitas dijawab dengan cukup percaya diri bahwa WFH efektif (Gambar 10). Meskipun demikian, ketika capaian kinerja yang ditanyakan, responden menyadari ketercapaiannya tetap lebih rendah daripada WFO (Gambar 7). Ragam implementasi perlu diberi kerangka standar minimal. Sistem manajemen SDM dengan demikian dapat menjadi acuan utama. Penilaian kinerja salah satu yang termaktub dalam sistem manajemen SDM. Penelitian terkait sistem manajemen SDM, terutama dalam pengukuran telah ditinjau oleh para peneliti (Boon et al., 2019). Boon et al. (2019) dalam tinjauan sistematis berdasarkan 495 studi empiris menemukan beragamnya konseptualisasi sistem SDM menghasilkan ragam penilaian pula. Tinjauan sistematik ini menunjukkan bahwa sistem SDM sangat bergantung pada latar belakang jenis industri, kultur organisasi, dan peraturan perundang-undangan (Boon et al., 2019). Dikaitkan dengan implementasi sistem SDM PT di Indonesia, nampaknya masukan berarti terutama dikaitkan dengan pergeseran implementasi kerja yang bukan hanya dari kantor, maka sistem SDM PT sangat perlu mendefinisikan ulang penjaminan mutu dengan standar utamanya.

Monitoring WFH mendapatkan perhatian dari para responden. Terkait dengan kebijakan karyawan bekerja dari rumah, sebanyak $73 \%$ responden menyatakan pendapatnya bahwa efektifitas kebijakan tersebut akan berjalan baik apabila ada pengaturan sistem berkerja dari rumah secara terstruktur, misalnya memiliki unit atau task force yang memantau pelaksanaan WFH, menyusun pedoman harian karyawan bekerja dari rumah dan mengadakan pelatihan untuk kelancaran penggunaan fasilitas atau pelatihan-pelatihan lain yang dapat meningkatkan kompetensi karyawan, dan juga adanya mekanisme pemantauan karyawan yang bekerja dari rumah secara periodik (Gambar 13). Hasil penelitian ini menunjukkan perlunya kontrol terdekat, yaitu di dalam unit, yang dilakukan oleh para kepala unitnya.

Studi serupa mengenai unit dan tipe kepala unit berkaitan dengan WFH telah dilakukan sebelumnya (Koivisto \& Rice, 2016). Studi Koivisto dan Rice (2016) menyatakan unit dengan kepala unit bertipe in-group (secara internal dihargai dan memberikan kepercayaan dan kebebasan internal 
dalam kelompoknya) yang mendukung WFH, maka kepala unit ini akan mendapatkan respect yang tinggi serta dukungan dari pimpinan yang lebih tinggi darinya. Sebagai perwakilan unitnya, kepala unit dengan tipe ini akan lebih mudah membagikan informasi yang relevan dengan unitnya dan memberikan pengaruh positif bagi anggota unitnya untuk melakukan self-evaluation dan menghargai diri dengan bermakna. Sama dengan harapan para responden dalam penelitian ini, bahwa mutu kerja dapat ditingkatkan dengan kejelasan fungsi (job description) yang diturunkan dari kebijakan universitas dengan pemantauan dan direksi oleh kepala unitnya. Koivisto dan Rice (2016) menyarankan perlunya sistem manajemen SDM secara luas yang ditata oleh organisasi dengan detil hingga penunjukkan kepala unit (immediate supervisor) yang aktif dan punya peran dalam proses WFH.

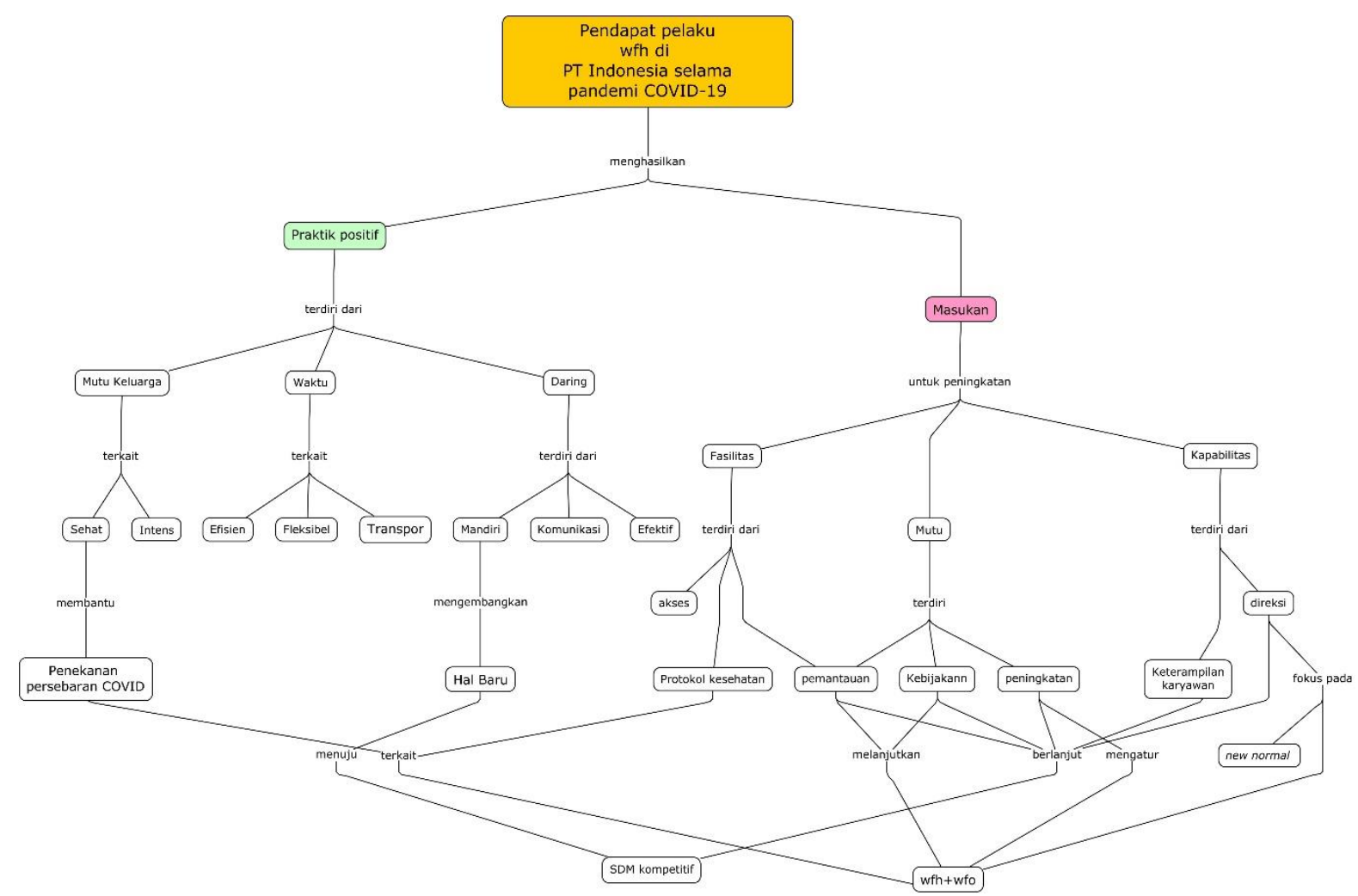

Gambar 13. Peta Konsep Keterkaitan Hasil Survei Mengenai WFH pada PT di Indonesia

Sisi evaluasi WFH menurut responden memberikan pandangan baru mengenai WFH di PT. Pendapat dari pertanyaan tertutup dan terbuka menunjukkan kemauan berubah dari SDM PT di Indonesia. Masa sulit ini sudah memberikan peluang pembelajaran yang baik untuk kebiasaan kerja WFH. Keberlanjutan WFH di masa kenormalan baru maupun masa setelah pandemi usai tampaknya dapat dilanjutkan menjadi kebijakan dan praktik baik. Pilihan WFH dengan fleksibilitas waktu dan mutu keluarga yang baik (Hunter et al., 2019) sudah menjadi tanda untuk terus dilakukannya WFH. Tampaknya hal-hal positif yang dirasakan oleh SDM dapat menjadi titik awal studi tentang kepuasan kerja melalui WFH. Agenda ini merupakan masukan bagi penelitian selanjutnya. Sangat mungkin temuan seperti studi di Jerman mengenai kepuasan kerja WFH akan meningkatkan retensi SDM di institusi (Kröll et al., 2018); bila hal ini terjadi maka mutu SDM PT juga dapat ditingkatkan melalui WFH yang baik.

Kombinasi WFH+WFO adalah alternatif akan sangat mungkin memberikan efisiensi biaya bagi penyelenggara PT. Aspek finansial pembiayaan SDM dari uang transpor dapat dialihkan menjadi fasilitas kerja dari rumah, misalnya akses internet. Pada saat tulisan ini dilaporkan, Kemdikbud telah memberikan bantuan kuota internet kepada insan pendidikan tinggi yaitu dosen dan mahasiswa. Meskipun demikian, paket untuk staf unit pendukung tidak disediakan. Dalam kerangka ini, PT perlu mulai menghitung bagaimana mekanisme pembiayaan ini diletakkan dalam kerangka efisiensi dan efektivitas kinerja karyawan PT. Dengan demikian, melalui perubahan ini dapat dipelajari 
standar pembiayaan SDM PT di Indonesia. Opsi WFH dan kombinasi WFH+WFO sangat mungkin memberikan peluang lebih jauh lagi bagi akses pendidikan tinggi sendiri. Penekanan pada biaya operasional dapat dialihkan pada pengurangan biaya pendidikan tinggi, tentu setelah hal-hal ini dibahas dan diperhitungkan dengan tuntas.

Dalam Gambar 13 mengenai peta konsep keterkaitan WFH dan aspek-aspek penjaminan mutu, terdapat konsep protokol kesehatan untuk WFH. Hal ini sebagai masukan berarti oleh para responden untuk memberikan bukan saja protokol kesehatan fisik, namun juga kesehatan mental. Pendapat responden ini sangat berarti serta sejalan dengan penelitian mengenai well-being karyawan WFH (Charalampous et al., 2019). Dalam telaah sistematik, tim peneliti menunjukkan kesehatan mental bagi karyawan WFH (salah satunya, psikosomatik) belum ditelaah dalam penelitian-penelitian terdahulu. Temuan pendapat responden dalam penelitian ini dapat menjadi awalan agar perhatian pada protokol kesehatan di masa kenormalan baru maupun dalam pilihan WFH dapat diperhatikan oleh manajemen SDM perguruan tinggi.

Aspek peningkatan kapabilitas SDM PT dalam WFH ialah masukan yang krusial (Gambar 13). Selain pelatihan, informasi teknis yang disebarkan dengan baik, merata, disertai dengan bantuan nyata (misalnya helpdesk daring) akan sangat membantu SDM PT berkembang lebih bermutu. Sumber informasi bersifat knowledge sharing perlu ditetapkan dalam sistem yang dapat diakses oleh SDM dengan mudah. Perpustakaan dimiliki oleh seluruh PT di Indonesia, oleh karena itu sistem pun sebenarnya sudah terbangun. Knowledge sharing dapat dimulai dari perpustakaan dengan memuat petunjuk teknis virtual working space, atau petunjuk lain berkaitan dengan fasilitas daring (Rysavy \& Michalak, 2020).

\section{SIMPULAN}

Penelitian ini menunjukkan aspek-aspek penjaminan mutu terhadap manajemen SDM perguruan tinggi, pada masa pandemi dan kenormalan baru melalui praktik atau pengalaman nyata para pelakunya. Berdasarkan temuan, terdapat praktik positif dalam pengambilan keputusan WFH yang sudah ditentukan dengan persiapan memadai dalam masa darurat. Aspek praktik positif selama WFH dari segi waktu, mutu keluarga, dan laku daring untuk bekerja telah dipandang sebagai tumpuan yang kuat untuk lebih meningkatkan mutu WFH di masa mendatang. Untuk itu, terdapat masukan utama untuk meningkatkan fasilitas WFH, mutu, dan kapabilitas SDM. Dalam meningkatkan mutu WFH tersebut, sangat diperlukan kebijakan, standar, serta direksi pimpinan hingga level pimpinan unit dengan tertata dalam sistem manajemen SDM. Sorotan hasil penelitian ini terutama pada mekanisme pemantauan kinerja SDM PT saat WFH. Dalam hal peningkatan kapabilitas untuk lebih bermutu, maka PT perlu menyediakan akses pengayaan keterampilan bagi karyawannya. Hal ini dapat diwujudkan dengan berbagai cara, termasuk membagikan informasi dengan rata bagi karyawan melalui sistem knowledge sharing. Keberlanjutan WFH dan kombinasi WFH+WFO dapat direncanakan dengan matang oleh PT dalam kerangka peningkatan mutu pendidikan tinggi melalui SDM yang bermutu, bekerja secara efisien dan efektif.

\section{UCAPAN TERIMA KASIH}

Ucapan terima kasih kami sampaikan bagi segenap pihak mitra perguruan tinggi yang berkenan memberi respon dalam penelitian ini.

\section{DAFTAR PUSTAKA}

Boon, C., Den Hartog, D. N., \& Lepak, D. P. (2019). A systematic review of human resource management systems and their measurement. Journal of Management, 45(6), 2498-2537. https://doi.org/10.1177/0149206318818718

Charalampous, M., Grant, C. A., Tramontano, C., \& Michailidis, E. (2019). Systematically reviewing remote e-workers' well-being at work: A multidimensional approach. European Journal of Work and Organizational Psychology, 28(1), 51-73. https://doi.org/10.1080/1359432X.2018.1541886 
Croucher, R., \& Rizov, M. (2015). MNEs and flexible working practices in Mauritius. The International Journal of Human Resource Management, 26(21), 2701-2717. https://doi.org/10.1080/09585192.2014.934898

Hokke, S., Bennetts, S. K., Crawford, S., Leach, L., Hackworth, N. J., Strazdins, L., Nguyen, C., Nicholson, J. M., \& Cooklin, A. R. (2020). Does flexible work 'work' in Australia? A survey of employed mothers' and fathers' work, family and health. Community, Work \& Family, 1-19. https://doi.org/10.1080/13668803.2019.1704397

Hunter, E. M., Clark, M. A., \& Carlson, D. S. (2019). Violating work-family boundaries: Reactions to interruptions at work and home. Journal of Management, 45(3), 1284-1308. https://doi.org/10.1177/0149206317702221

Kaduk, A., Genadek, K., Kelly, E. L., \& Moen, P. (2019). Involuntary vs. voluntary flexible work: Insights for scholars and stakeholders. Community, Work \& Family, 22(4), 412-442. https://doi.org/10.1080/13668803.2019.1616532

Kholili, A. N., \& Fajaruddin, S. (2020). Manajemen strategik peningkatan mutu lembaga pendidikan Muhammadiyah di Kabupaten Gunungkidul. Jurnal Akuntabilitas Manajemen Pendidikan, 8(1), 53-69. https://doi.org/10.21831/jamp.v8i1.31630

Koivisto, S., \& Rice, R. E. (2016). Leader prototypicality moderates the relation between access to flexible work options and employee feelings of respect and leader endorsement. The International Journal of Human Resource Management, 27(22), 2771-2789. https://doi.org/10.1080/09585192.2015.1126337

Kotey, B., \& Sharma, B. (2016). Predictors of flexible working arrangement provision in small and medium enterprises (SMEs). The International Journal of Human Resource Management, 27(22), 2753-2770. https://doi.org/10.1080/09585192.2015.1102160

Kröll, C., Nüesch, S., \& Foege, J. N. (2018). Flexible work practices and organizational attractiveness in Germany: The mediating role of anticipated organizational support. The International Journal of Human Resource Management, 32(3), 1-30. https://doi.org/10.1080/09585192.2018.1479876

Kusumah, E. P., \& Yusuf, S. (2020). Perspektif mahasiswa terhadap kualitas "branding" perguruan tinggi. Jurnal Akuntabilitas Manajemen Pendidikan, 8(1), 24-33. https://doi.org/10.21831/jamp.v8i1.30132

Nijp, H. H., Beckers, D. G. J., van de Voorde, K., Geurts, S. A. E., \& Kompier, M. A. J. (2016). Effects of new ways of working on work hours and work location, health and job-related outcomes. Chronobiology International, 33(6), 604-618. https://doi.org/10.3109/07420528.2016.1167731

Nizam, N. (2020). Potret transformasi digital: Mendadak daring-19. In Potret pendidikan tinggi di masa COVID-19. Direktorat Jenderal Pendidikan Tinggi, Kementerian Pendidikan dan Kebudayaan.

Pitt-Catsouphes, M., James, J. B., McNamara, T., \& Cahill, K. (2015). Relationships between managers who are innovators/early adopters of flexible work options and team performance. Journal of Change Management, 15(3), 167-187. https://doi.org/10.1080/14697017.2015.1035665

Rysavy, M. D. T., \& Michalak, R. (2020). Working from home: How we managed our team remotely with technology. Journal of Library Administration, 60(5), 532-542. https://doi.org/10.1080/01930826.2020.1760569

Sulaiman, A., \& Wibowo, U. B. (2016). Implementasi sistem penjaminan mutu internal sebagai upaya meningkatkan mutu pendidikan di Universitas Gadjah Mada. Jurnal Akuntabilitas Manajemen Pendidikan, 4(1), 17-32. https://doi.org/10.21831/amp.v4i1.8197 
Waizenegger, L., McKenna, B., Cai, W., \& Bendz, T. (2020). An affordance perspective of team collaboration and enforced working from home during COVID-19. European Journal of Information Systems, 29(4), 1-14. https://doi.org/10.1080/0960085X.2020.1800417

Williams, P., Cathcart, A., \& McDonald, P. (2018). Signals of support: Flexible work for mutual gain. The International Journal of Human Resource Management, 32(3), 1-25. https://doi.org/10.1080/09585192.2018.1499669 